\title{
EVOLUTION OF SOME COMPONENTS OF AGROECOSYSTEMS PRODUCTIVITY FROM VINGA PLAIN IN WATER STRESS SITUATIONS
}

\author{
Daniel DICU, Iacob BORZA，Dorin ȚĂRAU, \\ University of Agricultural Sciences and Veterinary Medicine of Banat Timisoara, Calea Aradului Str., No. 119 \\ dicudanield@gmail.com
}

Keywords: no-tillage, soil, moisture, component, agro-ecosystem

\section{Summary}

The researches are inscribed on line of substantiation of durable agricultural system, having main objective the prominence of quantitative and qualitative modifications made on agro-system level under the effect of no-tillage system for wheat, maize and soybeans.

The experimental field is placed on a cambium chernozem, with a medium content of clay, dominant in the Prodagro West Arad agrocentre and representative for a large surface in the Banat-Crisana Plain.

The passing to no-till system change the structure of technological elements, through less soil works, so the impact on agro-system is different comparing with conventional tillage, first less the intervention pressure on agro-system ant secondly appears new interactions, new equilibriums and disequilibriums.

Considering the evolution of soil humidity, the observations made monthly (by taking soil samples and laboratory determinations) for the three cultures showed that in the no-till system, there are more uniform values in the soil profile, and in the variants where the deep work of soil was made it could be observed a low increase of the water volume in the soil.

\section{INTRODUCTION}

Appeared in the Mesolithic Era as a way of producing the needs for everyday life by cultivating plants and husbandry, agriculture became at the same time with the evolution of humans and society a branch of the material production, which involves all the works and methods used for obtaining alimentary products and some prime matters by using the soil in this purpose.

The conventional tillage system, generalized for crop cultivation in our country, includes a large number of works designed to make conditions more favorable for crop sowing and plant development.

This agriculture system disrupt, often very serious, the balance in agricultural ecosystems, produce crops pollution, soil pollution and groundwater or surface water pollution and is very often too expensive in comparison with the financial possibilities of the farmers.

Unconventional tillage system, thought the idea of optimal in terms of technological, economic and environmental, for certain area, unit or parcel, is the basis of the cultivation technologies of alternative and sustainable agriculture.

Sustainable development, characterized by productivity, profitability, environmental friendliness and ability to conserve resources, involves the development of tillage systems through proper energy management, combined with increasing diversity of agro-ecosystems and environmental management in plant protection (Borza et all. ,2002).

The no-tillage technology belongs to the agricultural systems that have to role to conserve the soil, being known in the modern agriculture from the 1950s when on the American continent were settled up the technologies with minimum works in order to find some practical methods for reducing and stopping the soil erosion, a phenomenon that was more and more aggressive on the fields cultivated as an conventional system (Guş P., A. Puscu, 1999).

In Romania the first stationary experiment with the no-till technology was made by ICCPT Fundulea Institute in 1966 at the maize crop. Other researches treating the minima works system also state in brief about the no-till crop system, either regarding the economical efficiency or regarding the diseases' and the pest's evolution (Andru Monica, 2004).

The passing to no-till system change the structure of technological elements, through less soil works, so the impact on agro-system is different comparing with conventional tillage, first lessing the intervention pressure on agro-system ant secondly appears new interactions, new equilibriums and disequilibriums (Canarache A, et all, 1991).

The researches regarding the evolution of the agro-ecosystems' quality and productivity from the Vinga High Plain in the no-till crop system tries to highlight the quality and quantity changes emerged in the agricultural ecosystem. The no-till crop system was applied at the wheat, maize and soybean crops.

\section{MATERIAL AND METHOD}

The experimental field is placed on a cambic chernozem, with a medium content of clay, dominant in the Prodagro West Arad agro-centre and representative for a large surface in the Banat-Crisana Plain, the experiment being situated at approximately $500 \mathrm{~m}$ SW from the Andagra farm, located on the Arad cadastral territory, coordinates $46^{0} 7{ }^{\prime} 55^{\prime} \mathrm{N}$ latitude and $21^{0} 17^{\prime} 45^{\prime \prime}$ E longitude, $115 \mathrm{~m}$ altitude. 
The experiment has three factors, being of the type $2 \times 2 \times 3$, with subdivided parcels into 4 repetitions (144 parcels). The surface of one plot is of $27 \mathrm{sm}(3 \times 9)$, the total surface of the experiment being of $3888 \mathrm{sm}$.

The experimental factors are: Factor A - the technological system (A1 - without deep soil working, A2 with deep soil working), Factor B- the culture system (B1- classic culture system, B2- No-till culture system), Factor C- fertilizers doses (C1- $\left.\mathrm{N}_{0} \mathrm{P}_{0} \mathrm{~K}_{0}, \mathrm{C} 2-\mathrm{N}_{80} \mathrm{P}_{80} \mathrm{~K}_{80}, \mathrm{C} 3-\mathrm{N}_{160} \mathrm{P}_{80} \mathrm{~K}_{80}\right)$.

The examination of ecopedological conditions, were made according to "The Pedological Studies Elaboration Methodology “, (vol. I,II,III) of ICPA Bucharest, in 1987 and Romanian Taxonomic System of Soils (SRTS-2003).

\section{RESULTS AND DISCUSSIONS}

From the geomorphological point of view the perimeter on which are located the experiments belongs to the large physical -geographic unity called the Vinga High Plain.Vinga high plain is the oldest and the most complex among Banat-Crisana plains and extends south of Mures everglade, west of Lipova hills, north of Bega low plain , east of Galatca plain. It is formed at the convergence of hills glacisist, shaped by a net of flowing waters and erosion valleys (T,ărău D, et all, 2003).

The area where the experiment was placed is in the North-Western part of the High Plain of Vinga, above the 3rd terrace of Mures river, on the alignment New Tisa, Felnac, Secusigiu, at $100-120 \mathrm{~m}$ height and it has an aspect of tabular plain with cvasi-horizontal surfaces on which there are many small micro depressions and valleys.

Hydrographically, the perimeter where the experiment is placed belongs to the hydrographic basin of Mures river which flows at about 2-3 km north from this. The pedo-phreatic levels are at 5,1-10 m depth (they don't interfere in the pedo-genesis processes) in flat areas and between 1,5-3,0 m depth in the valleys (Țărău D, et all, 2003).

The climate is a temperate-continental one with Mediterranean influences, the medium multi-annual temperature being of $10,4{ }^{\circ} \mathrm{C}$ (table 1 ) and the multi-annual rainfall 593,5 $\mathrm{mm}$ (table 2).

Table 1

Monthly, yearly and multi-annual medium temperature at

Arad meteorological station

\begin{tabular}{|c|c|c|c|c|c|c|c|c|c|c|c|c|c|}
\hline Year & \multicolumn{10}{|c|}{ Month } \\
\hline & IX & X & XI & XII & I & II & III & IV & V & VI & VII & VIII & Yearly \\
\hline $\mathbf{0 7 - - 0 8}$ & 14,5 & 10,2 & 3,8 & $-0,4$ & 1,1 & 3,2 & 7,0 & 11,7 & 17,1 & 21,8 & 22,1 & 21,7 & 11,1 \\
\hline $\mathbf{0 8 - - 0 9}$ & 15 & 12 & 6,6 & 3,3 & $-1,6$ & 0,7 & 5,9 & 14 & 17,6 & 20 & 23,2 & 22,9 & 11,6 \\
\hline normal & 16,3 & 10,7 & 5,3 & 0,6 & $-1,8$ & 0,8 & 5,4 & 10,9 & 16,0 & 19,0 & 20,8 & 20,2 & 10,4 \\
\hline \multicolumn{10}{|c|}{ Differences } \\
\hline $\mathbf{0 7 - - 0 8}$ & $-1,8$ & $-0,5$ & $-1,5$ & $+1,2$ & $+2,9$ & $+2,4$ & $+1,6$ & $+0,8$ & $+1,1$ & $+2,8$ & $+1,3$ & $+1,5$ & $+0,7$ \\
\hline $\mathbf{0 8 - - 0 9}$ & $-1,3$ & $+1,3$ & $+1,3$ & $+2,7$ & $+0,2$ & $-0,1$ & $+0,5$ & $+3,1$ & $+1,6$ & $+1,0$ & $+2,4$ & $+2,7$ & $+1,2$ \\
\hline
\end{tabular}

Regarding rainfall, due to cyclonic activity and the invasions of moist air from the west, southwest and northwest, rainfall within the area studied are quantitatively higher than in other low plain areas (with similar altitude) of Romania, the specific of these area is determined by the Baric movement and relief characteristics and the annual average recorded value of $593.5 \mathrm{~mm}$, with large swings from year to year, $405.1 \mathrm{~mm}$ in the 1999-2000 agricultural year and respectively $741.6 \mathrm{~mm}$ in the 2004-2005 agricultural year (tab 2).

Table 2

Monthly, yearly and multi-annual precipitations at

Arad meteorological station

\begin{tabular}{|c|c|c|c|c|c|c|c|c|c|c|c|c|c|}
\hline Year & \multicolumn{10}{|c|}{ Month } \\
\hline & IX & $\mathbf{X}$ & XI & XII & I & II & III & IV & V & VI & VII & VIII & Yearly \\
\hline $\mathbf{0 7 - 0 8}$ & 87,6 & 45,6 & 102,7 & 32,4 & 17,6 & 10,5 & 71,0 & 24,4 & 33,7 & 43,2 & 38,7 & 50,2 & 557,6 \\
\hline $\mathbf{0 8 - 0 9}$ & 45,7 & 18,6 & 56,5 & 48,1 & 17,6 & 10,5 & 44,5 & 40 & 46,2 & 78,4 & 37,2 & 29,8 & 473,1 \\
\hline normal & 44.2 & 46.6 & 48.5 & 45.3 & 35.1 & 30.9 & 35.6 & 48.1 & 65.6 & 81.1 & 60.3 & 52.2 & 593.5 \\
\hline \multicolumn{10}{|c|}{ Differences } \\
\hline $\mathbf{0 7 - - 0 8}$ & $+43,4$ & $-1,0$ & $+54,2$ & $-12,9$ & $-17,5$ & $-20,4$ & $+35,4$ & $-23,7$ & $-31,9$ & $-37,9$ & $-21,6$ & $-2,0$ & $-35,9$ \\
\hline $\mathbf{0 8 - - 0 9}$ & $+1,5$ & $+28,0$ & $-8,0$ & $+2,8$ & $-17,5$ & $-20,4$ & $+8,9$ & $-8,1$ & $-19,4$ & $-2,7$ & $-23,1$ & $-22,4$ & $-120,4$ \\
\hline
\end{tabular}

To assess the impact of weather on different agricultural systems, the precipitation data were compared with the significance of rainfall (reference range compared with the requirements of agriculture) being used data from Agroclimatic Resources of Timis county (Table 3). 
The significance of rainfall $(\mathrm{mm})$ in relation to the requirements of agriculture

\begin{tabular}{|c|c|c|c|c|c|}
\hline \multirow{2}{*}{ Interval } & \multicolumn{5}{|c|}{ The significance of rainfall } \\
\cline { 2 - 5 } & Very dry & Dry & Satisfactory & Optimum & Surplus \\
\hline September to October & $<40$ & $41-60$ & $61-80$ & $81-150$ & $>150$ \\
\hline November to March & $<100$ & $101-150$ & $151-200$ & $201-300$ & $>300$ \\
\hline April & $<20$ & $21-30$ & $31-40$ & $41-70$ & $>70$ \\
\hline May to July & $<100$ & $101-150$ & $151-200$ & $201-300$ & $>300$ \\
\hline Yearly & $<350$ & $351-450$ & $451-600$ & $601-700$ & $>700$ \\
\hline
\end{tabular}

The significance of rainfall $(\mathrm{mm})$ in relation to the requirements of agriculture,

Table 4 the weather station Arad in 2007-2009 periods

\begin{tabular}{|c|c|c|c|c|c|c|}
\hline $\begin{array}{c}\text { Agricultural } \\
\text { year }\end{array}$ & & IX-X & XI-III & IV & V-VII & Annual \\
\hline \multirow{2}{*}{$2007-2008$} & $\mathrm{~mm}$ & 133,2 & 234,2 & 24,4 & 115,6 & 557,6 \\
\cline { 2 - 7 } & Significance & Optimum & Optimum & Dry & Dry & Satisfactory \\
\hline \multirow{2}{*}{$2008-2009$} & $\mathrm{~mm}$ & 64,3 & 177,2 & 40 & 161,8 & 473,1 \\
\cline { 2 - 7 } & Significance & Satisfactory & Satisfactory & Satisfactory & Satisfactory & Satisfactory \\
\hline
\end{tabular}

As a result of the cosmic-atmospheric and telluric factors intervention, under a specific vegetation to the forest steppe, in the zone were created cambium chernozems, specific to the researched perimeter.

The analyzed soil has an acid reaction $(5,9-6,8)$ in the first $80 \mathrm{~cm}$ of the soil profile, neutral between 80 $125 \mathrm{~cm}$ and low alkaline between $125-200 \mathrm{~cm}$ depth.

The mobile phosphorus content (P) in the worked soil (Ap) has medium values $(35,0 \mathrm{ppm})$ at the limit of alert threshold (concerning the nutrition lack) the mobile potassium supply $(\mathrm{K})$ having medium values (153 ppm), values which are lower on with the profile.

The humus reserve in the first $50 \mathrm{~cm}$ is high, and the natrium index (I.N.) has medium values in the worked layer (Ap) and also in the $0-45 \mathrm{~cm}$ layer.

Soil's texture, a very stable physical feature, is medium clay on the whole profile. The Apparent Density (DA) has medium values in the worked layer from the classic system, high in the first $10 \mathrm{~cm}$ in no-till system and very high in the middling third of the soil profile in the two systems.

The Total Porosity (PT) has low values in the $0-33 \mathrm{~cm}$ interval, and also in the $45-96 \mathrm{~cm}$ one. The aeration porosity, which represents all the pores occupied with air when the soil is in optimum humidity conditions, has very low values, excepting the worked layer from the classic system, where it has low values and the first $10 \mathrm{~cm}$ depth in No-till system where the values are very low.

After establishing the cultures, among the specific maintaining works there were made a series of observations in order to identify and stock take the main damaging species from the vegetal or pathogen flora and fauna, which frequently populate the wheat, maize and soybeans agro-ecosystems. The field cultivated as No-Till system is exposed to a higher degree of weeding compared to the classic one. The plants that developed in the wheat, maize and soybeans cultures had an easy progress, especially those which multiplicate vegetative or by seeds (Cyrsium arvense L., Convolvulus arvensis L., Sonchus arvensis L., Cynodon dactylon L., Sorghum halepense L., Rubus caesius L.) or with small seeds and surface germination (Stellaria media L., Capsella bursa pastoris L., Lamium purpureum L.) and infesting those that develop widely in the stubble (Setaria sp., Polygonum convolvulus L., Matricaria inodora L., Rubus caesius L).

Considering the evolution of soil humidity, the observations made monthly (by taking soil samples and laboratory determinations) for the three cultures showed that in the no-till system, there are more uniform values in the soil profile, and in the variants where the deep work of soil was made it could be observed a low increase of the water volume in the soil.

The wather reserve from soil, between 0-100 cm in 2007-2008 agricultural year (Table 5), 2008-2009 agricultural year (Table 6), 2009-2010 agricultural year (Table 7), comparing with field capacity values, are more less in all the experimental factors . 
Water reserve between $0-100 \mathrm{~cm}(\mathrm{~W} \mathrm{~mm})$ comparing with

Table 5

field capacity $(\mathrm{CC}=381,76 \mathrm{~mm})$ in 2007-2008 agricultural year

\begin{tabular}{|c|c|c|c|c|c|c|c|c|c|c|c|}
\hline \multicolumn{2}{|c|}{ Culture } & \multicolumn{10}{|c|}{ Characteristic periods } \\
\hline & & \multicolumn{2}{|c|}{ IX-X } & \multicolumn{2}{|c|}{ XI-III } & \multicolumn{2}{|c|}{ IV } & \multicolumn{2}{|c|}{ V-VII } & \multicolumn{2}{|c|}{ VIII } \\
\hline & & 2008 & Deviation & 2008 & Deviation & 2008 & Deviation & 2008 & Deviation & 2008 & Deviation \\
\hline \multirow{2}{*}{ Weath } & Clasic & 353,41 & $-28,35$ & 351,31 & $-30,45$ & 344,20 & $-37,56$ & 245,76 & $-136,00$ & 268,51 & $-113,25$ \\
\hline & No-till & 313,04 & $-68,72$ & 342,50 & $-39,26$ & 335,55 & $-46,21$ & 264,80 & $-116,96$ & 269,80 & $-111,96$ \\
\hline \multirow{2}{*}{$\begin{array}{l}\text { Weath+ deep } \\
\text { work }\end{array}$} & Clasic & 353,41 & $-28,35$ & 363,06 & $-18,70$ & 371,40 & $-10,36$ & 214,19 & $-167,57$ & 260,44 & $-121,32$ \\
\hline & No-till & 313,04 & $-68,72$ & 351,99 & $-29,77$ & 361,85 & $-19,91$ & 212,81 & $-168,95$ & 255,67 & $-126,09$ \\
\hline \multirow[t]{2}{*}{ Maize } & Clasic & 302,46 & $-79,30$ & 348,89 & $-32,87$ & 364,21 & $-17,52$ & 264,24 & $-117,52$ & 297,67 & $-84,09$ \\
\hline & No-till & 366,76 & $-15,00$ & 375,26 & $-6,50$ & 369,41 & $-12,35$ & 284,83 & $-96,93$ & 303,77 & $-77,99$ \\
\hline \multirow{2}{*}{$\begin{array}{l}\text { Maize+ } \\
\text { deep work }\end{array}$} & Clasic & 302,46 & $-79,30$ & 360,43 & $-21,33$ & 366,02 & $-15,74$ & 262,63 & $-119,13$ & 243,91 & $-137,85$ \\
\hline & No-till & 366,76 & $-15,00$ & 375,83 & $-5,93$ & 370,80 & $-10,96$ & 300,43 & $-81,33$ & 322,46 & $-59,30$ \\
\hline \multirow[t]{2}{*}{ Soya } & Clasic & 283,46 & $-98,30$ & 348,32 & $-33,44$ & 363,93 & $-17,83$ & 254,25 & $-127,51$ & 248,69 & $-133,07$ \\
\hline & No-till & 323,52 & $-58,24$ & 339,56 & $-42,20$ & 346,30 & $-35,46$ & 297,67 & $-84,09$ & 314,97 & $-66,79$ \\
\hline \multirow{2}{*}{$\begin{array}{l}\text { Soya + deep } \\
\text { work }\end{array}$} & Clasic & 283,46 & $-98,30$ & 359,89 & $-21,87$ & 364,95 & $-16,81$ & 275,38 & $-106,38$ & 308,00 & $-73,76$ \\
\hline & No-till & 323,52 & $-58,24$ & 359,39 & $-22,37$ & 354,32 & $-27,44$ & 301,58 & $-80,18$ & 325,64 & $-56,12$ \\
\hline
\end{tabular}

Water reserve between $0-100 \mathrm{~cm}$ (W $\mathrm{mm}$ ) comparing with

field capacity $(\mathrm{CC}=381,76 \mathrm{~mm})$ in 2008-2009 agricultural year

\begin{tabular}{|c|c|c|c|c|c|c|c|c|c|c|c|}
\hline \multirow{3}{*}{\multicolumn{2}{|c|}{ Culture }} & \multicolumn{10}{|c|}{ Characteristic periods } \\
\hline & & \multicolumn{2}{|c|}{ IX-X } & \multicolumn{2}{|c|}{ XI-III } & \multicolumn{2}{|r|}{ IV } & \multicolumn{2}{|c|}{$\mathrm{V}-\mathrm{VII}$} & \multicolumn{2}{|r|}{ VIII } \\
\hline & & 2009 & Deviation & 2009 & Deviation & 2009 & Deviation & 2009 & Deviation & 2009 & Deviation \\
\hline \multirow[t]{2}{*}{ Weath } & Clasic & 266,16 & $-115,60$ & 316,03 & $-65,73$ & 307,73 & $-74,03$ & 315,76 & $-66,00$ & 237,37 & $-144,39$ \\
\hline & No-till & 255,20 & $-126,56$ & 352,39 & $-29,37$ & 311,37 & $-70,39$ & 312,43 & $-69,33$ & 216,92 & $-164,84$ \\
\hline \multirow{2}{*}{$\begin{array}{l}\text { Weath+ deep } \\
\text { work }\end{array}$} & Clasic & 272,69 & $-109,07$ & 360,87 & $-20,89$ & 375,64 & $-6,91$ & 246,69 & $-135,07$ & 234,54 & $-147,22$ \\
\hline & No-till & 253,57 & $-128,19$ & 353,61 & $-28,15$ & 303,10 & $-78,66$ & 306,38 & $-75,38$ & 228,63 & $-153,13$ \\
\hline \multirow[t]{2}{*}{ Maize } & Clasic & 267,38 & $-114,38$ & 340,67 & $-41,09$ & 316,16 & $-65,60$ & 314,75 & $-67,01$ & 237,10 & $-144,76$ \\
\hline & $\overline{\text { No-ti }}$ & 267,52 & 24 & 351,78 & $-29,98$ & 302,21 & $-79,55$ & 288,72 & $-93,04$ & 220,18 & 58 \\
\hline \multirow{2}{*}{\begin{tabular}{|l|} 
Maize+ \\
deep work
\end{tabular}} & Clasic & 274,64 & $-107,12$ & 369,11 & $-12,65$ & 339,27 & $-42,49$ & 268,81 & $-112,95$ & 229,66 & $-152,10$ \\
\hline & No-till & 248,76 & $-133,00$ & 350,62 & $-31,14$ & 299,15 & $-82,61$ & 282,97 & $-98,79$ & 223,81 & $-157,95$ \\
\hline \multirow[t]{2}{*}{ Soya } & Clasic & 269,91 & $-111,85$ & 368,12 & $-13,64$ & 313,54 & $-68,22$ & 321,28 & $-60,48$ & 231,24 & $-150,52$ \\
\hline & No-till & 277,06 & $-104,70$ & 375,56 & $-6,20$ & 320,34 & $-61,42$ & 320,17 & $-65,59$ & 235,71 & $-146,05$ \\
\hline \multirow{2}{*}{\begin{tabular}{|l|}
$\begin{array}{l}\text { Soya }+ \text { deep } \\
\text { work }\end{array}$ \\
\end{tabular}} & Clasic & 205,75 & $-176,01$ & 270,89 & $-110,87$ & 247,61 & $-134,15$ & 265,43 & $-116,33$ & 237,20 & $-144,50$ \\
\hline & No-till & 292,24 & $-89,52$ & 374,13 & $-7,63$ & 319,77 & $-61,99$ & 318,27 & $-63,49$ & 243,61 & $-138,15$ \\
\hline
\end{tabular}

Water reserve between 0-100 $\mathrm{cm}(\mathrm{W} \mathrm{mm})$ comparing with

field capacity $(C C=381,76 \mathrm{~mm})$ in 2009-2010 agricultural year

\begin{tabular}{|c|c|c|c|c|c|c|c|c|c|c|c|}
\hline \multirow{3}{*}{\multicolumn{2}{|c|}{ Culture }} & \multicolumn{10}{|c|}{ Characteristic periods } \\
\hline & & \multicolumn{2}{|c|}{ IX-X } & \multicolumn{2}{|c|}{ XI-III } & \multicolumn{2}{|c|}{ IV } & \multicolumn{2}{|c|}{ V-VII } & \multicolumn{2}{|c|}{ VIII } \\
\hline & & 2010 & Deviation & 2010 & Devi & 2010 & De & 2010 & Deviation & 2010 & Deviation \\
\hline \multirow[t]{2}{*}{ Weath } & Clasic & 251,07 & $-130,69$ & 303,96 & $-77,80$ & 326,06 & $-55,70$ & 167,13 & $-214,63$ & 141,54 & $-240,22$ \\
\hline & No-till & 34,28 & $-147,48$ & 293,37 & $-88,39$ & 309,21 & $-72,55$ & 282,06 & $-99,70$ & 218,24 & 3,52 \\
\hline \multirow{2}{*}{$\begin{array}{l}\text { Weath+ } \\
\text { deep work }\end{array}$} & Clasic & 261,90 & $-119,86$ & 317,48 & $-64,28$ & 333,09 & $-48,67$ & 201,80 & $-179,96$ & 141,61 & $-240,15$ \\
\hline & No-till & 43,06 & $-138,70$ & 307,52 & $-74,24$ & 309,74 & $-72,02$ & 186,78 & $-194,98$ & 140,01 & $-241,75$ \\
\hline \multirow[t]{2}{*}{ Maize } & Clasic & 251,26 & $-130,50$ & 296,63 & $-85,13$ & 320,00 & $-61,76$ & 316,93 & $-64,83$ & 224,19 & $-157,57$ \\
\hline & No-till & 252,28 & $-129,48$ & 303,72 & $-78,04$ & 327,59 & $-54,17$ & 296,88 & $-84,88$ & 186,33 & $-195,43$ \\
\hline \multirow{2}{*}{$\begin{array}{l}\text { Maize+ } \\
\text { deep work }\end{array}$} & Clasic & 268,40 & $-113,36$ & 313,97 & $-67,79$ & 338,20 & $-43,56$ & 208,53 & $-173,23$ & 166,69 & $-215,07$ \\
\hline & No-till & 272,30 & $-109,46$ & 317,94 & $-63,82$ & 320,95 & $-60,81$ & 216,92 & $-164,84$ & 190,90 & $-190,86$ \\
\hline \multirow[t]{2}{*}{ Soya } & Clasic & 252,19 & $-129,57$ & 301,40 & $-80,36$ & 313,60 & $-68,16$ & 180,22 & $-201,54$ & 138,70 & $-243,06$ \\
\hline & No-till & 239,34 & $-142,42$ & 292,7 & $-89,06$ & 317,26 & $-64,5$ & 306,77 & $-74,99$ & 203,79 & $-177,97$ \\
\hline \multirow{2}{*}{$\begin{array}{l}\begin{array}{l}\text { Soya }+ \\
\text { deep work }\end{array} \\
\end{array}$} & Clasic & 256,86 & $-124,90$ & 314,66 & $-67,10$ & 346,83 & $-34,93$ & 171,09 & $-210,67$ & 130,34 & $-251,42$ \\
\hline & No-till & 263,72 & $-118,04$ & 316,31 & $-65,45$ & 317,66 & $-64,1$ & 200,16 & $-181,60$ & 153,38 & $-228,38$ \\
\hline
\end{tabular}


About the yields obtained from the three cultures, in 2007-2010 agricultural year, there can be remarked the followings:for wheat, the yield was between $3795-4292 \mathrm{~kg} / \mathrm{ha}$, the highest yield of $4292 \mathrm{~kg} / \mathrm{ha}$, being registered in the classic system without no deep work of soil, in $\mathrm{N}_{160} \mathrm{P}_{80} \mathrm{~K}_{80}$ dose and the lowest of $3795 \mathrm{~kg} / \mathrm{ha}$ in the no-tillage system with the deep work of soil, in $\mathrm{N}_{0} \mathrm{P}_{0} \mathrm{~K}_{0}$ dose (table 8).

Table 8

Influence of the no-till system on to the wheat crop on the cambium chernozem medium clayey earth/ medium clayey earth from Arad

\begin{tabular}{|c|c|c|c|c|c|c|}
\hline & $\begin{array}{l}\text { Culture } \\
\text { system }\end{array}$ & Fertilization & Yield & $\%$ & $\begin{array}{c}\text { Differences } \\
\mathrm{Kg} / \mathrm{ha}\end{array}$ & Semnification \\
\hline \multirow{6}{*}{$\begin{array}{l}\text { Without deep } \\
\text { soil working }\end{array}$} & \multirow{3}{*}{ Clasic } & $\mathrm{N}_{0} \mathrm{P}_{0} \mathrm{~K}_{0}$ & 3931 & 100 & - & \\
\hline & & $\mathrm{N}_{80} \mathrm{P}_{80} \mathrm{~K}_{80}$ & 4094 & 104 & 163 & $* *$ \\
\hline & & $\mathrm{N}_{160} \mathrm{P}_{80} \mathrm{~K}_{80}$ & 4292 & 109 & 361 & $* * *$ \\
\hline & \multirow{3}{*}{ No-till } & $\mathrm{N}_{0} \mathrm{P}_{0} \mathrm{~K}_{0}$ & 3820 & 97 & -111 & 00 \\
\hline & & $\mathrm{N}_{80} \mathrm{P}_{80} \mathrm{~K}_{80}$ & 3983 & 101 & 52 & \\
\hline & & $\mathrm{N}_{160} \mathrm{P}_{80} \mathrm{~K}_{80}$ & 4130 & 105 & 199 & $* * *$ \\
\hline \multirow{6}{*}{$\begin{array}{l}\text { With deep soil } \\
\text { working }\end{array}$} & \multirow{3}{*}{ Clasic } & $\mathrm{N}_{0} \mathrm{P}_{0} \mathrm{~K}_{0}$ & 3886 & 99 & -45 & \\
\hline & & $\mathrm{N}_{80} \mathrm{P}_{80} \mathrm{~K}_{80}$ & 4043 & 103 & 112 & $*$ \\
\hline & & $\mathrm{N}_{160} \mathrm{P}_{80} \mathrm{~K}_{80}$ & 4147 & 105 & 216 & $* * *$ \\
\hline & \multirow{3}{*}{ No-till } & $\mathrm{N}_{0} \mathrm{P}_{0} \mathrm{~K}_{0}$ & 3795 & 97 & -136 & 0 \\
\hline & & $\mathrm{N}_{80} \mathrm{P}_{80} \mathrm{~K}_{80}$ & 3998 & 102 & 67 & \\
\hline & & $\mathrm{N}_{160} \mathrm{P}_{80} \mathrm{~K}_{80}$ & 4079 & 104 & 148 & $* *$ \\
\hline
\end{tabular}

For maize the obtained yield had values of 5541-6458 kg/ha, the highest yield of $6458 \mathrm{~kg} / \mathrm{ha}$, being registered in classic system without deep work of soil, in $\mathrm{N}_{160} \mathrm{P}_{80} \mathrm{~K}_{80}$, and the lowest of $5541 \mathrm{~kg} / \mathrm{ha}$ in no-tillage system with deep work of soil, in $\mathrm{N}_{0} \mathrm{P}_{0} \mathrm{~K}_{0}$. (table 9)

Table 9

Influence of the no-till system on to the maize crop on the cambium chernozem medium clayey earth/ medium clayey earth from Arad

\begin{tabular}{|c|c|c|c|c|c|c|}
\hline & $\begin{array}{l}\text { Culture } \\
\text { system }\end{array}$ & Fertilization & Yield & $\%$ & $\begin{array}{c}\text { Differences } \\
\mathrm{Kg} / \mathrm{ha}\end{array}$ & Semnification \\
\hline \multirow{6}{*}{$\begin{array}{l}\text { Without deep } \\
\text { soil working }\end{array}$} & \multirow{3}{*}{ Clasic } & $\mathrm{N}_{0} \mathrm{P}_{0} \mathrm{~K}_{0}$ & 6024 & 100 & - & \\
\hline & & $\mathrm{N}_{80} \mathrm{P}_{80} \mathrm{~K}_{80}$ & 6206 & 103 & 182 & \\
\hline & & $\mathrm{N}_{160} \mathrm{P}_{80} \mathrm{~K}_{80}$ & 6458 & 107 & 434 & $* * *$ \\
\hline & \multirow{3}{*}{ No-till } & $\mathrm{N}_{0} \mathrm{P}_{0} \mathrm{~K}_{0}$ & 6021 & 100 & -3 & \\
\hline & & $\mathrm{N}_{80} \mathrm{P}_{80} \mathrm{~K}_{80}$ & 6095 & 101 & 71 & \\
\hline & & $\mathrm{N}_{160} \mathrm{P}_{80} \mathrm{~K}_{80}$ & 6425 & 107 & 401 & $* *$ \\
\hline \multirow{6}{*}{$\begin{array}{l}\text { With deep soil } \\
\text { working }\end{array}$} & \multirow{3}{*}{ Clasic } & $\mathrm{N}_{0} \mathrm{P}_{0} \mathrm{~K}_{0}$ & 5954 & 99 & -70 & \\
\hline & & $\mathrm{N}_{80} \mathrm{P}_{80} \mathrm{~K}_{80}$ & 6430 & 107 & 406 & $* *$ \\
\hline & & $\mathrm{N}_{160} \mathrm{P}_{80} \mathrm{~K}_{80}$ & 6377 & 106 & 353 & $* *$ \\
\hline & \multirow{3}{*}{ No-till } & $\mathrm{N}_{0} \mathrm{P}_{0} \mathrm{~K}_{0}$ & 5541 & 92 & -483 & 000 \\
\hline & & $\mathrm{N}_{80} \mathrm{P}_{80} \mathrm{~K}_{80}$ & 5851 & 97 & -173 & \\
\hline & & $\mathrm{N}_{160} \mathrm{P}_{80} \mathrm{~K}_{80}$ & 5993 & 99 & -31 & \\
\hline
\end{tabular}

For soybeans the yield was 2998-3342 kg/ha, the highest yield of $3342 \mathrm{~kg} / \mathrm{ha}$ being registered in the classic system with deep working of soil, in $\mathrm{N}_{80} \mathrm{P}_{80} \mathrm{~K}_{80}$, and the lowest of $2998 \mathrm{~kg} / \mathrm{ha}$ in the no-till system with the deep work of soil, in $\mathrm{N}_{0} \mathrm{P}_{0} \mathrm{~K}_{0}$ (table 10). 
Table 10

Influence of the no-till system on to the soybean crop on the cambium chernozem medium clayey earth/medium clayey earth from Arad

\begin{tabular}{|c|c|c|c|c|c|c|}
\hline & $\begin{array}{l}\text { Culture } \\
\text { system }\end{array}$ & Fertilization & Yield & $\%$ & $\begin{array}{c}\text { Differences } \\
\mathrm{Kg} / \mathrm{ha}\end{array}$ & Semnification \\
\hline \multirow{6}{*}{$\begin{array}{l}\text { Without deep } \\
\text { soil working }\end{array}$} & \multirow{3}{*}{ Clasic } & $\mathrm{N}_{0} \mathrm{P}_{0} \mathrm{~K}_{0}$ & 3084 & 100 & - & \\
\hline & & $\mathrm{N}_{40} \mathrm{P}_{80} \mathrm{~K}_{80}$ & 3398 & 110 & 314 & $* * *$ \\
\hline & & $\mathrm{N}_{80} \mathrm{P}_{80} \mathrm{~K}_{80}$ & 3478 & 113 & 395 & $* * *$ \\
\hline & \multirow{3}{*}{ No-till } & $\mathrm{N}_{0} \mathrm{P}_{0} \mathrm{~K}_{0}$ & 3086 & 100 & 2 & \\
\hline & & $\mathrm{N}_{40} \mathrm{P}_{80} \mathrm{~K}_{80}$ & 3322 & 108 & 238 & $* * *$ \\
\hline & & $\mathrm{N}_{80} \mathrm{P}_{80} \mathrm{~K}_{80}$ & 3391 & 110 & 307 & $* * *$ \\
\hline \multirow{6}{*}{$\begin{array}{l}\text { With deep } \\
\text { soil working }\end{array}$} & \multirow{3}{*}{ Clasic } & $\mathrm{N}_{0} \mathrm{P}_{0} \mathrm{~K}_{0}$ & 3112 & 101 & 28 & \\
\hline & & $\mathrm{N}_{40} \mathrm{P}_{80} \mathrm{~K}_{80}$ & 3233 & 105 & 149 & $* * *$ \\
\hline & & $\mathrm{N}_{80} \mathrm{P}_{80} \mathrm{~K}_{80}$ & 3342 & 108 & 258 & $* * *$ \\
\hline & \multirow{3}{*}{ No-till } & $\mathrm{N}_{0} \mathrm{P}_{0} \mathrm{~K}_{0}$ & 2998 & 97 & -86 & 000 \\
\hline & & $\mathrm{N}_{40} \mathrm{P}_{80} \mathrm{~K}_{80}$ & 3033 & 98 & -51 & 00 \\
\hline & & $\mathrm{N}_{80} \mathrm{P}_{80} \mathrm{~K}_{80}$ & 3136 & 102 & 52 & $* *$ \\
\hline
\end{tabular}

DL $\quad \begin{array}{lll}5 \% & 30.46\end{array}$

$1 \% \quad 41.41$

$0,1 \% 55.46$

\section{CONCLUSIONS}

Considering the evolution of soil humidity, the observations made monthly for the three cultures showed that in the no-till system, there are more uniform values in the soil profile, and in the variants where the deep work of soil was made it could be observed a low increase of the water volume in the soil.

Even if the productions obtained in the classic system are superior than those obtained in the no-till system, considering the economical costs for establishing a culture in the no-till system are lower, the same as the pressure made upon the soil (by reducing the number of passes with the agricultural machines and installations), than the classic system.

The obtained production results can not give a recommendation for one of the two experimented culture systems, but they are valuable data (concerning the evaluation of the natural and manmade resources) by the studies made in the field and laboratory, for the fundament in the future of some adequate technologies for the climatic and soils conditions of the area where the research was made and also for other similar areas.

\section{REFERENCES}

1. Andru Monica, 2004- Influența tehnologiei No-till asupra evoluției bolilor şi dăunătorilor în culturile de grâu si porumb. Teză de doctorat, USAMVB Timişoara pag 221

2. Borza I., Țărău D., Țărău Irina ,2002, Limitation Factors and terrain yeild including measures in Vinga high plain, Scientifical Papers, Faculty of Agriculture, XXXXIV, Ed. Oriz. Univ. Pg. 69-76

3. Canarache A, Elisabeta Dumitru, 1991. Criterii pedologice de evaluare a sistemelor de lucrări minime de soluri. Ed. Acad., Univ. Athenaeum, Cluj-Napoca.

4. Guş P., A. Puscu, 1999. Cercetări privind impactul sistemului de lucrare asupra porozității şi structurii solului. Simp. Int. 21-22 Oct., Cluj-Napoca.

5. Dumitru Elisabeta, Gus P., Enache Roxana, Dumitru M, 1990- Efecte permanente a unor practici agricole asupra stării fizice a solului., Ed. Risoprint, Cluj pag 203

6. Țărău D, Borza I, Țărău Irina, Vlad H, Dologa D, Jurcuț T, 2003- Mediul natural, cadru structural si funcțional în definirea factorilor edafici în vestul României. Ştiința Solului, vol XXXVIII, Ed. Sigmata Timişoara, pag 137-161 